\title{
Kajian Fatwa Dewan Syariah Nasional Tentang Mudharabah
}

\author{
Fadhilah Mursid \\ UIN Raden Fatah Palembang \\ Fadhilah.Mursyid@gmail.com
}

\begin{abstract}
Until now, mudharabah is still carried out in people's lives even though it has been modified to a degree. Even in Islamic Financial Institutions, mudaraba becomes a mainstay product that is often offered by customers. With the increasing number of LKS that makes mudharabah as one of its flagship products. MUI as an institution that has the authority to issue fatwas related to Islamic economics through DSN considers it necessary to issue a fatwa on mudharabah so that the procedure is carried out in accordance with Islamic Sharia. Regarding the fatwa it is interesting to analyze how the implementation of the DSN fatwa on mudaraba in the study of muamalah figh. The researcher uses a descriptive qualitative research method which discusses comprehensively using various sources of primary and secondary literature data relating to the MUI DSN fatwas on mudharabah. The results of the study concluded that overall the existing fatwa was in accordance with the provisions contained in the treasury of Islamic economics. However, in carrying out legal construction as a legal standing, it is still very global, especially in the use of figh proposals. Even from a number of fatwas, there is a similar tendency in legal construction of different content of the fatwa.
\end{abstract}

Keywords: mudharabah, fatwa DSN MUI

\begin{abstract}
Abstrak
Sampai saat ini, mudharabah masih dijalankan dalam kehidupan masyarakat meskipun telah sedikit banyak mengalami modifikasi. Bahkan dalam Lembaga Keuangan Syariah, mudharabah menjadi produk andalan yang kerap ditawarkan oleh para nasabah. Dengan semakin banyaknya LKS yang menjadikan mudharabah sebagai salah satu produk andalannya. MUI sebagai lembaga yang memiliki otoritas mengeluarkan fatwa terkait ekonomi Islam melalui DSN menganggap perlu mengeluaran fatwa tentang mudharabah agar tatacara yang dijalankan tersebut dilakukan sesuai dengan Syariah Islam. Mengenai fatwa tersebut menarik untuk dianalisa bagaimana implementasi fatwa DSN tentang mudharabah dalam kajian fikih muamalah. Peneliti menggunakan metode penelitian deskriptif kualitatif yang mana membahas secara komprehensif dengan menggunakan berbagai sumber data literatur baik primer maupun sekunder berkaitan fatwa-fatwa DSN MUI tentang mudharabah. Hasil penelitian dapat disimpulkan bahwa secara keseluruhan fatwa yang ada sudah sesuai dengan ketentuan-ketentuan yang ada dalam khazanah keilmuan ekonomi Islam. Namun dalam melakukan konstruksi hukum sebagai legal standing masih sangat global, khususnya dalam penggunaan kaidah usul fikih. Bahkan dari beberapa fatwa yang ada, ada kecenderungan yang sama dalam melakukan konstruksi hukum terhadap fatwa yang berbeda isi.
\end{abstract}

Kata Kunci: mudharabah, fatwa DSN MUI 


\section{PENDAHULUAN}

Syariat Islam sebagai suatu ajaran yang dibawa oleh Rasul terakhir, mempunyai keunikan tersendiri. Syariat ini bukan saja bersifat komprehensif, tetapi juga universal. Komprehensif berarti bahwa syariat Islam merangkum seluruh aspek kehidupan baik ritual (ibadah) maupun sosial (muamalah). Dalam kehidupan bermuamalat, Islam telah memberikan garis kebijakan yang jelas. Salah satu contoh kegiatan bermuamalat adalah transaksi bisnis. Transaksi bisnis sebagai kegiatan muamalah merupakan kerja sama yang mengatur tentang masalah keduniaan, sehingga selalu mengikuti perkembangan dan keadaan zaman, hal ini perlu diadakan penalaran melalui pikiran sehat yang sesuai dengan prinsip syariat Islam. Salah satu bentuk kerja sama dalam muamalah yaitu kerja sama antara pemilik modal dan pekerjaannya adalah bagi hasil (profit sharing), yang dilandasi oleh rasa saling tolongmenolong (Hasan, 2003: 18).

Bentuk kerja sama antara pemilik modal dan pekerja yang dilandasi dengan itikad baik untuk mendapatkan keuntungan dalam khazanah ekonomi Islam lebih dikenal dengan konsep mudharbah. Konsep mudharabah sebagai suatu bentuk kerja sama antara pemilik modal dan pekerja sudah ada bahkan sebelum masa kenabian, sampai masa Rasulullah kegiatan mudharabah masih berjalan dengan baik dan mendapat legitimasi dari Rasul. Sampai saat ini, mudharabah masih dijalankan dalam kehidupan masyarakat meskipun telah sedikit banyak mengalami modifikasi. Bahkan dalam Lembaga Keuangan Syariah, mudharabah menjadi produk andalan yang kerap ditawarkan oleh para nasabah. Dengan semakin banyaknya LKS yang menjadikan mudharabah sebagai salah satu produk andalannya. MUI sebagai lembaga yang memiliki otoritas mengeluarkan fatwa terkait ekonomi Islam melalui DSN menganggap perlu mengeluaran fatwa tentang mudharabah agar tatacara yang dijalankan tersebut dilakukan sesuai dengan Syariah Islam. Mengenai fatwa tersebut menarik untuk dianalisa bagaimana implementasi fatwa DSN tentang mudharabah dalam kajian fikih muamalah.

\section{METODE PENELITIAN}

Metode penelitian yang digunakan dalam penelitian ini menggunakan metode penelitian deskriptif kualitatif. Bogdan dan Taylor (1975) dalam (Moleong, 2012:4) mendefinisikan metodologi kualitatif sebagai proses penelitian yang menghasilkan data deskriptif berupa katakata tertulis atau lisan dari orang-orang dan perilaku yang dapat diamati. Berdasarkan pengertian tersebut maka dalam penelitan ini peneliti bermaksud untuk menjelaskan dan menggambarkan secara komprehensif dengan menggunakan berbagai sumber data literatur baik sumber primer 
maupun sekunder yang berkaitan fatwa-fatwa DSN MUI tentang mudharabah.

\section{PEMBAHASAN}

\section{Konsep Mudharabah}

Mudharabah merupakan salah satu dari bentuk kontrak yang lahir sejak zaman Rasulullah SAW. Dalam bahasa Arab ada beberapa istilah yang digunakan untuk bentuk bisnis ini yaitu qiradh, dan mudharabah. Kedua istilah ini tidak ada perbedaan secara prinsip. Perbedaan dalam istilah penggunaan dalam sebuah transaksi tersebut kemungkinan disebabkan oleh faktor geografis. Imam Abu Hanifah dan Ahmad min Hanbal di Irak menggunakan istilah mudharabah, sedangkan Imam Malik dan Syafi'i menggunakan istilah qiradh atau muqaradhah, mengikuti kebiasaan di hijaz Hisranuddin, 2008:14).

Secara etimologis, mudharabah berasal dari kata الضرب yang berarti bepergian atau berjalan. Selain الضرب disebut juga القرض dari القراض berarti القطع yang artinya potongan, (Hendi, 2008:135). Menurut penduduk hijaz mudharabah disebut juga dengan muqaradah (qiradh). Seperti dikemukakan oleh Muhammad bin Ismail "Qirad dengan kasroh qof adalah kerja sama pemilik modal dengan amil dengan pembagian laba, dalam istilah ahli hijaz disebut mudharabah diambil dari kata (berjalan di muka bumi) karena menurut kebiasaan laba itu diperoleh dengan berjalan-jalan atau mendistribusikan harta" (Hendi, 2008:135).

Sedangkan menurut Sayyid Sabiq, mudharabah juga disebut qiradh, yang mana kata qiradh berasal dari kata alqardh yang artinya a-qat'u yakni pemotongan, hal ini karena orang yang memiliki harta memotong (mengambil) sebagian dari hartanya untuk diperdagangkan dan mengambil sebagian untuk keuntungannya. Selain itu mudharabah juga disebut muamalah, yang maksudnya adalah akad antara dua belah pihak yang mengharuskan salah satu dari keduanya untuk menyerahkan sejumlah uang kepada pihak lain untuk diperniagakan, dengan ketentuan keuntungannya dibagi sesuai dengan kesepakatan di antara keduanya (Sabiq, 2009: 276).

Mudharabah menurut ahli fiqh merupakan suatu perjanjian di mana pemilik modal menyerahkan modalnya kepada pekerja (pedagang) untuk diperdagangkan, sedangkan keuntungan dagang itu dibagi menurut kesepakatan bersama. Apabila terjadi kerugian dalam perdagangan tersebut, kerugian ini ditanggung sepenuhnya oleh pemilik modal. Definisi ini menunjukkan bahwa yang diserahkan oleh pekerja (ahli dagang) tersebut adalah berbentuk modal, bukan manfaat seperti penyewaan rumah (Dahlan, 1996: 1196).

Pasa masa Nabi, praktek mudharabah juga pernah dilakukan antara Siti Khodijah dengan Nabi. saat itu Siti Khodijah mempercayakan barang 
dagangannya untuk dijual oleh Nabi Muhammad SAW, ke luar negeri. Dalam kasus ini, Siti Khodijah berperan sebagai pemilik modal (Shahibul mal) sedangkan Nabi Muhammad SAW, berperan sebagai pelaksana usaha (mudharib), dengan begitu bentuk kontrak antar dua pihak di mana satu pihak berperan sebagai pemilik modal dan mempercayakan sejumlah modalnya untuk dikelola oleh pihak kedua, yakni si pelaksana usaha, dengan tujuan untuk mendapatkan untung disebut akad mudharabah (Karim, 2004:204).

Secara teknis, mudharabah adalah akad kerja sama antara dua pihak di mana pihak pertama (sahibul mal) menyediakan seluruh $(100 \%)$ modal, sedangkan pihak lainnya menjadi pengelola. Keuntungan usaha secara mudharabah dibagi menurut kesepakatan yang dituangkan dalam kontrak, sedangkan apabila rugi ditanggung oleh pemilik modal selama kerugian itu bukan akibat kelalaian si pengelola. Seandainya kerugian itu diakibatkan karena kecurangan atau kelalaian si pengelola harus bertanggung jawab atas kerugian tersebut (Asy-Syarbasyi, 2001:95).

Dari berbagai pengertian yang ada terkait mudharabah, dapat dipahami bahwa akad mudharabah merupakan bentuk perjanjian antara dua pihak atau lebih (di era sekarang pihak bisa perseorangan atau badan hukum), di mana salah satu pihak berkongsi dalam modal (dalam hal ini bisa berupa uang atau barang) yang dalam fikih disebut shohibul mal, sedangkan pihak lain berkongsi dalam pekerjaan yang dalam fikih di sebut mudharib. Sedangkan mengenai hasil dari perjanjian tersebut, baik keuntungan maupun kerugian yang timbul akan di bagi berdasarkan syarat dan ketentuan yang telah disepakati oleh para pihak.

\section{Landasan Hukum Mudharabah}

Para ulama mazhab sepakat bahwa mudharabah hukumnya dibolehkan berdasarkan al-Qur'an, sunnah, ijma' dan qiyas. Hanya saja, hukum ini merupakan pengecualian dari masalah penipuan (gharar) dan ijaroh yang belum diketahui. Sebagaimana dalam firman Allah QS. AlMuzammil ayat 20:

$$
\text { وآخرون يضربون في الأرض يبتغون من فضل الله. }
$$

Artinya: Dan yang lain berjalan di bumi mencari sebagian karunia Allah.

Sedangkan dalil sunahnya adalah sebagai berikut:

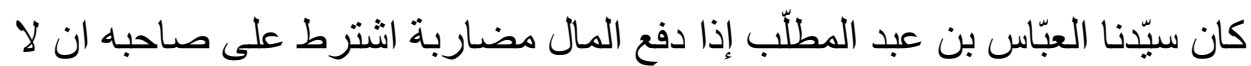

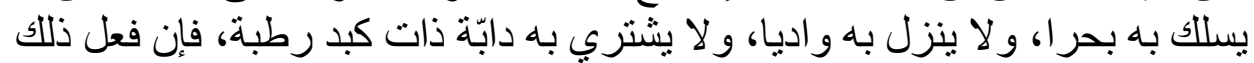

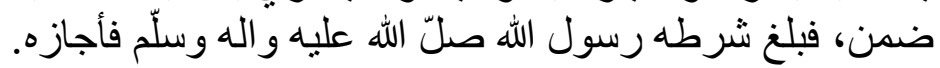

Artinya: Abbas bin Abdul Muthallib jika menyerahkan harta sebagai mudharabah, ia mensyaratkan kepada mudharibnya agar tidak mengarungi lautan dan tidak menuruni lembah, serta tidak membeli hewan ternak, Jika 
persyaratan itu dilanggar, ia harus menanggung resikonya. Ketika persyaratan yang ditetapkan Abbas itu di dengar Rasulullah, beliau membolehkannya.

Ibnu Taimiyah menetapkan landasan hukum mudharabah dengan ijmak yang berlandaskan pada nash. Mudharabah sudah terkenal di kalangan bangsa Arab jahiliah, terlebih di kalangan suku Quraisy. Mayoritas orang Arab bergelut di bidang perdagangan. para pemilik modal memberikan modal mereka kepada pengelola. Rasulullah pun pernah mengadakan perjalanan dengan membawa modal orang lain sebelum beliau diangkat menjadi nabi. Beliau juga pernah mengadakan perjalanan dagang dengan mengelola modal Hadijah. Ketika Islam datang, Rasulullah mengakui dan menyetujui akad ini. Para sahabat pun melakukan perjalanan dagang dengan mengelola orang lain berdasarkan akad mudharabah sementara beliau tidak melarang hal ini. Sunnah merupakan perbuatan, perkataan dan pengakuan Rasulullah. maka ketika beliau telah mengakui mudharabah, berarti mudharabah telah ditetapkan oleh sunah (Az-Zuhaili, 2011:478).

Sedangkan dalil qiyas adalah bahwa mudharabah dapat di qiyaskan pada akad musaqah atau akad pemeliharaan tanaman. Karena terkadang ada seseorang yang memiliki harta tetapi tidak bisa mengelola atau menjalankan hartanya untuk usaha, namun sebaliknya terkadang ada pula seseorang yang memiliki keahlian dalam mengelola harta tetapi tidak punya harta. Pada keadaan yang demikian itu, akad mudharabah seolah mendapat legitimasi atas kebolehannya (Samsudin, 1997:399).

\section{Rukun dan Syarat Mudharabah}

Menurut ulama mazhab Hanafi, rukun mudharabah hanyalah ijab (ungkapan penyerahan modal dari pemiliknya) dan kabul (ungkapan penerima modal dan persetujuan mengelola modal dari pedagang). Jumhur ulama menyatakan bahwa rukun mdharabah alah orang yang berakad, modal, keuntungan, kerja, dan akad (Dahlan: 1197). Sedangkan menurut mazhab Syafi'i rukun qiradh atau mudharabah (Mardani, 2013:197), ada enam yaitu:

1) Pemilik barang yang menyerahkan barang-barangnya

2) orang yang bekerja, yaitu mengelola harta yang diterima dari pemilik barang

3) Akad Mudharabah

4) Modal

5) Pekerjaan pengelolaan harta sehingga menghasilkan untung

6) Keuntungan

Menurut Pasal 188 dalam Kompilasi Hukum Ekonomi Syariah (KHES), rukun mudharabah ada tiga yaitu:

1) Shahibul mal (pemilik modal) 
2) Mudharib (Pelaku usaha)

3) Akad (kontrak perjanjian).

Adapun syarat mudharabah adalah Terkait dengan para pihak yang melakukan transaksi haruslah orang yang cakap bertindak hukum dan cakap diangkat sebagai wakil. Sedangkat terkait dengan dengan modal menurut Sayyid Sabiq mudharabah memiliki syarat-syarat sebagai berikut:

1) Modal harus tunai. Jika modal berbentuk emas batangan, perhiasan, atau barang dagangan maka akad mudharabah tak sah.

2) Jumlah modal diketahui dengan jelas. Hal ini bertujuan agar mol yang dikelola dapat dipisahkan dari keuntungan yang akan dibagi untuk keduabelah pihak sesuai dengan kesepakatan.

3) Pembagian keuntungan antara shohibul mal dengan mudharib harus jelas prosentasinya.

4) Mudharabah dilakukan tanpa ikatan. Pendapat ini juga dikemukakan oleh Imam Malik dan Syafi'i. Namun menurut Imam Abu Hanifah dan Ahmad dalam mudharabah boleh dilakukan dengan ikatan dan boleh juga dilakukan tanpa ikatan (Sabiq, 2009:278-279).

5) Syarat bentuk usaha atau pekerjaan dalam mudharabah adalah yang diserahkan bisa berbentuk keahlian, keterampilan, selling skill, management skill, dan lain-lain (Karim, 2004:206).

\section{Jenis Mudharabah}

Dilihat dari segi transaksi yang dilakukan pemilik modal dengan pekerja, Mudharabah ada dua jenis, yaitu muthlaqoh dan muqayyadah (Az-Zuhaili, 2011:479).

\section{1) Mudharabah mutlaqoh}

Mudharabah mutlaqoh atau penyerahan modal secara mutlak tanpa syarat, dalam hal ini pekerja bebas mengelola modal itu dengan usaha apa saja yang menurutnya akan mendatangkan keuntungan dan di daerah mana saja yang ia inginkan.

2) Mudharabah muqayyadah

Mudharabah muqayyadah adalah bentuk kerja sama yang berkebalikan dari mudharabah mutlaqoh, dalam mudharabah muqayad ini pemilik dananya memberikan batasan kepada pengelola dana mengenai lokasi, cara dan atau objek investasi atau sektor usaha. Mudharabah ini disebut juga investasi terikat.

\section{Berakhirnya Mudharabah}

Akad mudharabah menjadi batal atau berakhir (Sabiq, 2009:281), apabila terjadi hal-hal sebagai berikut:

1. Tidak terpenuhinya syarat sahnya akad mudharabah. apabila salah atau dari syarat-syarat sahnya mudharabah tidak terpenuhi, sedangkan 
mudharib telah menerima harta dan membuatnya untuk usaha maka dia hanya berhak memperoleh upah sewajarnya karena dia telah melakukan transaksi dengan seizin pemilik modal dan melakukan pekerjaan sehingga dia pantas mendapatkan upah. Keuntungan yang ada menjadi milik pemilik modal dan kerugian menjadi tanggung jawab pemilik modal karena dalam kondisi ini mudharib hanya bersetatus sebagai seorang pekerja yang tidak bertanggung jawab kecuali apabila ada unsur kesengajaan.

2. Mudharib lalai dalam memelihara harta, atau melakukan sesuatu yang bertentangan dengan tujuan diadakannya akad. Dalam kondisi yang semayam ini, akad mudharabah menjadi batal dan mudharib bertanggung jawab atas resik kerugian dari harta tersebut.

3. Mudharib atau pemilik modal meninggal dunia. Jika salah atau dari keduabelah pihak meninggal dunia, maka kas mudharabah menjadi batal.

\section{Fatwa Dewan Syariah Nasional Seputar Fatwa}

Fatwa merupakan salah satu institusi dalam hukum Islam untuk memberikan jawaban dan solusi terhadap problem yang dihadapi umat. Bahkan umat Islam pada umumnya menjadikan fatwa sebagai rujukan di dalam bersikap dan bertingkah laku. Dalam perkembangan ekonomi Syariah, fatwa mempunyai peranan penting dan menjadi aspek organik dalam bangunannya, fatwa juga menjadi alat ukur bagi kemajuan ekonomi Syariah di Indonesia. Fatwa ekonomi Syariah yang telah hadir itu secara teknis menyuguhkan model pengembangan bahkan pembaharuan fikih muamalah maliyah (Sula dan Mufti, 221). Secara fungsional, fatwa memiliki fungsi tabyin dan tawjih. Tabyin artinya menjelaskan hukum yang merupakan regulasi praksis bagi lembaga keuangan, khususnya yang diminta praktisi ekonomi Syariah ke DSN dan taujih, yakni memberikan guidance (petunjuk) serta pencerahan kepada masyarakat luas tentang norma ekonomi Syariah (Sula dan Mufti, 221).

\section{Fatwa DSN Tentang Mudharabah}

\section{Pertama : Ketentuan Pembiayaan:}

a) Pembiayaan Mudharabah adalah pembiayaan yang disalurkan oleh LKS kepada pihak lain untuk suatu usaha yang produktif.

b) Dalam pembiayaan ini LKS sebagai shahibul maal (pemilik dana) membiayai $100 \%$ kebutuhan suatu proyek (usaha), sedangkan pengusaha (nasabah) bertindak sebagai mudharib atau pengelola usaha. 
c) Jangka waktu usaha, tata cara pengembalian dana, dan pembagian keuntungan ditentukan berdasarkan kesepakatan kedua belah pihak (LKS dengan pengusaha).

d) Mudharib boleh melakukan berbagai macam usaha yang telah disepakati bersama dan sesuai dengan Syariah dan LKS tidak ikut serta dalam managemen perusahaan atau proyek tetapi mempunyai hak untuk melakukan pembinaan dan pengawasan.

e) Jumlah dana pembiayaan harus dinyatakan dengan jelas dalam bentuk tunai dan bukan piutang.

f) LKS sebagai penyedia dana menanggung semua kerugian akibat dari mudharabah kecuali jika mudharib (nasabah) melakukan kesalahan yang disengaja, lalai, atau menyalahi perjanjian.

g) Pada prinsipnya, dalam pembiayaan mudharabah tidak ada jaminan, namun agar mudharib tidak melakukan penyimpangan, LKS dapat meminta jaminan dari mudharib atau pihak ketiga. Jaminan ini hanya dapat dicairkan apabila mudharib terbukti melakukan pelanggaran terhadap hal-hal yang telah disepakati

h) Kriteria pengusaha, prosedur pembiayaan, dan mekanisme pembagian keuntungan diatur oleh LKS dengan memperhatikan fatwa DSN.

i) Biaya operasional dibebankan kepada mudharib.

j) Dalam hal penyandang dana (LKS) tidak melakukan kewajiban atau melakukan pelanggaran terhadap kesepakatan, mudharib berhak mendapat ganti rugi atau biaya yang telah dikeluarkan.

\section{Kedua : Rukun dan Syarat Pembiayaan:}

1) Penyedia dana (sahibul maal) dan pengelola (mudharib) harus cakap hukum.

2) Pernyataan ijab dan qabul harus dinyatakan oleh para pihak untuk menunjukkan kehendak mereka dalam mengadakan kontrak (akad), dengan memperhatikan hal-hal berikut:

a) Penawaran dan penerimaan harus secara eksplisit menunjukkan tujuan kontrak (akad).

b) Penerimaan dari penawaran dilakukan pada saat kontrak.

c) Akad dituangkan secara tertulis, melalui korespondensi, atau dengan menggunakan cara-cara komunikasi modern.

3) Modal ialah sejumlah uang dan/atau aset yang diberikan oleh penyedia dana kepada mudharib untuk tujuan usaha dengan syarat sebagai berikut:

a) Modal harus diketahui jumlah dan jenisnya.

b) Modal dapat berbentuk uang atau barang yang dinilai. Jika modal diberikan dalam bentuk aset, maka aset tersebut harus dinilai pada waktu akad. 
c) Modal tidak dapat berbentuk piutang dan harus dibayarkan kepada mudharib, baik secara bertahap maupun tidak, sesuai dengan kesepakatan dalam akad.

4) Keuntungan mudharabah adalah jumlah yang didapat sebagai kelebihan dari modal. Syarat keuntungan berikut ini harus dipenuhi:

a) Harus diperuntukkan bagi kedua pihak dan tidak boleh disyaratkan hanya untuk satu pihak.

b) Bagian keuntungan proporsional bagi setiap pihak harus diketahui dan dinyatakan pada waktu kontrak disepakati dan harus dalam bentuk prosentasi (nisbah) dari keuntungan sesuai kesepakatan. Perubahan nisbah harus berdasarkan kesepakatan.

c) Penyedia dana menanggung semua kerugian akibat dari mudharabah, dan pengelola tidak boleh menanggung kerugian apapun kecuali diakibatkan dari kesalahan disengaja, kelalaian, atau pelanggaran kesepakatan.

5) Kegiatan usaha oleh pengelola (mudharib), sebagai perimbangan (muqabil) modal yang disediakan oleh penyedia dana, harus memperhatikan hal-hal berikut:

a) Kegiatan usaha adalah hak eksklusif mudharib, tanpa campur tangan penyedia dana, tetapi ia mempunyai hak untuk melakukan pengawasan.

b) Penyedia dana tidak boleh mempersempit tindakan pengelola sedemikian rupa yang dapat menghalangi tercapainya tujuan mudharabah, yaitu keuntungan.

c) Pengelola tidak boleh menyalahi hukum Syariah Islam dalam tindakannya yang berhubungan dengan mudharabah, dan harus mematuhi kebiasaan yang berlaku dalam aktivitas itu.

\section{Ketiga : Beberapa Ketentuan Hukum Pembiayaan:}

1) Mudharabah boleh dibatasi pada periode tertentu.

2) Kontrak tidak boleh dikaitkan (mu'allaq) dengan sebuah kejadian di masa depan yang belum tentu terjadi.

3) Pada dasarnya, dalam mudharabah tidak ada ganti rugi, karena pada dasarnya akad ini bersifat amanah (yad al-amanah), kecuali akibat dari kesalahan disengaja, kelalaian, atau pelanggaran kesepakatan.

4) Jika salah satu pihak tidak menunaikan kewajibannya atau jika terjadi perselisihan di antara kedua belah pihak, maka penyelesaiannya dilakukan melalui Badan Arbitrasi Syariah setelah tidak tercapai kesepakatan melalui musyawarah.

\section{ANALISIS}

Fatwa merupakan salah satu metode dalam yuk Islam yang terdapat dalam al-Qur'an dan hadis untuk memberikan keterangan dan penjelasan 
mengenai hukum-hukum syariat Islam, ajaran-ajarannya dan araharahnya, Sebagai sebuah metode dalam memberikan penjelasan terhadap suatu masalah yang belum jelas status hukumnya atau bagai mana mekanisme implementasinya, maka fatwa menempati posisi yang sangat penting dan strategis. Fatwa DSN tentang mudharabah ini merupakan metode sekaligus sebagai legitimasi dalam menjelaskan bagaimana sebenarnya tata cara mudharabah yang sesuai syariat.

Secara keseluruhan fatwa DSN tentang mudharabah memang baik secara rukun dan syarat sudah sesuai dengan yang ada dalam khazanah kajian fikih muamalah. Namun, saya melihat bahwa dalam mengkonstruk fatwa ini dan beberapa fatwa terkait mudharabah kaidah yang digunakan sangatlah kaidah yang umum, kurang spesifik atau mendekati permasalahan yang sebenarnya. Selain itu, fatwa ini seolah hanya menjelaskan bagaimana konsep penyaluran mudharabah dari LKS kepada nasabah atau mudharib, dan tidak menjelaskan bagaimana konsep mudharabah secara komprehensif. Ada beberapa catatan yang menjadi kritik saya dalam fatwa tersebut.

Dalam ketentuan pembiayaan yang terdapat dalam fatwa DSN tersebut dikatakan bahwa:

"Pembiayaan Mudharabah adalah pembiayaan yang disalurkan oleh LKS kepada pihak lain untuk suatu usaha yang produktif"

Dalam posisi yang demikian, maka sebenarnya status bank adalah sebagai shohibul mal sedangkan pihak lain atau mudharib dari pihak nasabah. Perlu dipahami bahwa bank Syariah dalam penghimpunan dana umumnya menggunakan dua akad, yaitu akad wadai'ah (titipan) dan akad mudharabah (bagi hasil). Sehingga ketika bank Syariah dalam melakukan penghimpunan dana menggunakan akad mudharabah, saat itu bank Syariah berkedudukan sebagai mudharib atau pihak yang menerima dana dan akan mengelolanya untuk usaha, sedangkan nasabah penabung menjadi sohibul mal karena memberikan dana kepada bank untuk dikelola.

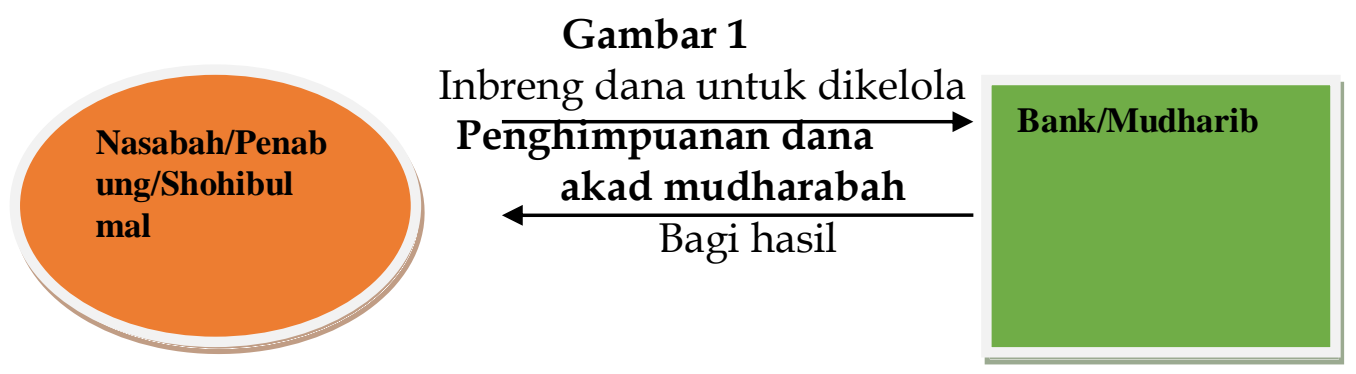

Dalam keadaan yang demikian, bank sebagai mudharib seharusnya menggunakan dana dari shohibul mal untuk kegiatan usaha. Namun dalam set yang bersamaan ketika bank menyalurkan dana, bank juga menggunakan akad mudharabah dengan nasabah lain yang memerlukan 
suntikan dana untuk usaha. Sehingga posisi bank berubah menjadi shohibul mal sedangkan nasabah peminjam dana menjadi mudharib.

\section{Gambar 2}
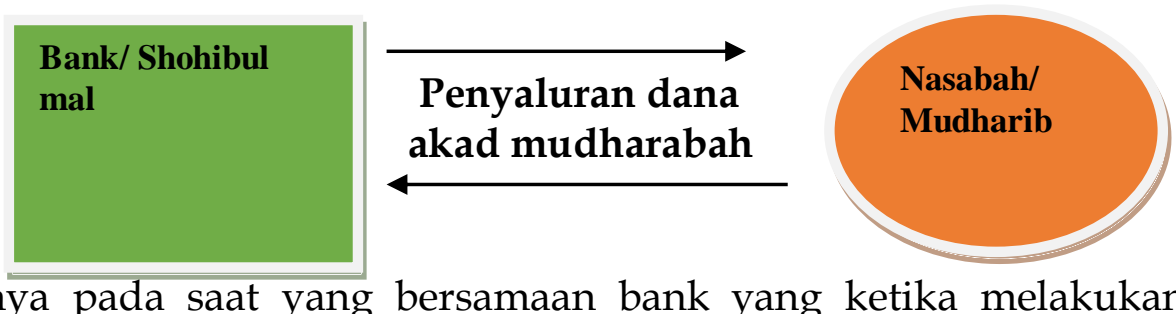

Artinya pada saat yang bersamaan bank yang ketika melakukan penghimpunan dana sebagai shohinul mal, dapat seketika menjadi mudharib ketika menyalurkan dana. Pada situasi yang demikian, fatwa DSN tersebut tidak menyinggung akan setiasi yang demikian, mengingat bank Syariah sebagai lembaga keuangan bukan personal. Akibatnya terdapat ketidak jelasan mengenai status bank dalam akan mudharbah ini, Karena bank pada awalnya sebagai mudharib justru melakukan mudharbah lain dengan pihak lain. Melihat realitas perbankan Syariah kita selama ini, sebenarnya bank tidak lain sebagai perantara dari orang yang mampu yang menyimpankan dananya dan mengucurkan dana tersebut untuk pihak lain yang membutuhkan untuk melakuakan usaha.

Dalam fikih muamalah, terkait tindakan mudharib yang melakukan mudharbah lain ada beberapa pandangan. Pertama, menurut ulama Hanafiah, mudharib tidak boleh melakukan mudharabah dengan modalnya pada orang lain, kecuali jika pemilik modal memberikan kuasa kepadanya. Kedua, Pendapat lain berasal dari pandangan Malikiyah, bahwa jika mudharib melakukan mudharbah lain adalah mudharib wajib menjamin modal jika dia melakukan qiradh kembali atas modal mudharbah pertama karena kesewenangannya. Dalam hal ini keuntungannya diberikan kepada mudharib kedua dan pemilik modal, sedangkan mudharib pertama tidak mendapat bagian keuntungan ini. Sedangkan menurut ulama Syafi'iyah berpendapat dalam pandangan yang paling sahih bahwa mudharib tidak boleh melakukan qiradh pada yang lain untuk berkongsi dengannya dalam pekerjaan dan keuntungan, sekalipun itu dengan seizin pemilik modal (Az-Zuhaili, 2011:497-499).

Untuk mengantisipasi keadaan yang demikian, seharusnya bank memiliki bentuk usaha sendiri. Selama ini bank hanya memutarkan dana dari satu nasabah ke nasabah yang lain, tanpa melakukan kegiatan usaha sendiri. Selama bank tidak memiliki usaha sendiri, maka selama itu bank dalam sistem perekonomian akan selalu memerankan peran sebagai perantara.

Selanjutnya, dalam akad mudharabah pada prinsipnya memang tidak memerlukan jaminan dari mudharib, karena mudharib tidak 
memiliki tanggung jawab jika terdapat resik kerugian, sepanjang tidak ada unsur kesengajaan. Dalam fatwa DSN tentang mudharabah DSN memfatwakan bahwa sebagai upaya antisipasi, LKS dapat meminta jaminan kepada mudharib sebagai langkah antisipasi jika terjadi kerugian yang disengaja. Dalam fatwa ini, dalam konstruksi fatwanya cenderung menggunakan kaidah usul fikih yang sangat umum, seperti kaidah "la dharoro wa la diror". Sehingga terlihat kecenderungan bahwa dam membuat fatwa DSN sangat longgar, padahal dalam konsep darurat sekalipun masih ada batasan-batasan yang harus dipenuhi. Menurut (Djazuli, 2010:164) setidaknya dalam fatwa tersebut perlu dimasukkan kaidah-kaidah sebagai berikut:

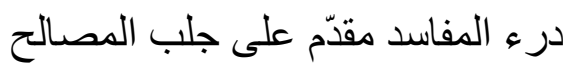

Sebagaimana dalam redaksi lain (Tamrin, 2010:189) disebutkan kaidah yang dimasukkan yakni:

$$
\text { الحاجة قد تنزل منزلة الضرورة. }
$$

Secara prinsip, saya sependapat demikian, karena berbisnis di era sekarang kita memang harus berhati-hati. Tetapi perlu dipahami bahwa, perlunya langkah antisipasi untuk mencegah terjadinya kerugian bukanlah keadaan darurat yang bersifat mutlak, karena hal tersebut sebenarnya hanya hajat yang dalam keadaan-keadaan tertentu memang bisa menempati keadaan darurat. Namun pada implementasinya, jaminan justru dijadikan bank sebagai tameng untuk terhindar dari kerugian, meskipun kerugian tersebut tanpa ada unsur kesengajaan ataupun kelalaian. Seharusnya penetapan jaminan itu diperbolehkan sepanjang memang dibutuhkan.

\section{Fatwa DSN Tentang Investasi Mudharabah Antarbank \\ Pertama : Ketentuan Umum}

1) Sertifikat investasi antarbank yang berdasarkan bunga, tidak dibenarkan menurut Syariah.

2) Sertifikat investasi yang berdasarkan pada akad Mudharabah, yang disebut dengan Sertifikat Investasi Mudharabah Antarbank (IMA), dibenarkan menurut Syariah.

3) Sertifikat IMA dapat dipindah tangankan hanya satu kali setelah dibeli pertama kali.

4) Pelaku transaksi Sertifikat IMA adalah:

a) Bank Syariah sebagai pemilik atau penerima dana.

b) Bank konvensional hanya sebagai pemilik dana.

\section{Kedua : Ketentuan Khusus}

Implementasi dari fatwa ini secara rinci diawasi oleh Dewan Pengawas Syariah pada bank Syariah dan oleh Bank Indonesia. 


\section{Ketiga : Penyelesaian Perselisihan}

Jika salah satu pihak tidak menunaikan kewajibannya atau jika terjadi perselisihan di antara para pihak, maka penyelesaiannya dapat dilakukan melalui Badan Arbitrasi Syariah yang berkedudukan di Indonesia setelah tidak tercapai kesepakatan melalui musyawarah.

\section{Keempat : Penutup}

Fatwa ini berlaku sejak tanggal ditetapkan, dengan ketentuan jika di kemudian hari ternyata terdapat kekeliruan, akan diubah dan disempurnakan sebagaimana mestinya.

\section{ANALISIS}

Bank berfungsi sebagai lembaga intermediasi antara pemilik dan pengguna dana dapat berpotensi mengalami kekurangan atau kelebihan likuiditas. Kekurangan likuiditas umumnya disebabkan oleh perbedaan jangka waktu antara penerimaan dan penanaman dana, sedangkan kelebihan likuiditas dapat terjadi karena dana yang terhimpun belum dapat disalurkan kepada pihak yang membutuhkan. Dalam rangka peningkatan pengelolaan dana bank, yaitu pengelolaan kelebihan dan kekurangan dana, maka perlu diselenggarakan pasar uang antarbank. Bank yang melakukan kegiatan usaha berdasarkan prinsip Syariah dapat mengelola kelebihan dan kekurangan dana secara efisien, maka diperlukan pasar uang antarbank berdasarkan prinsip Syariah.

Jika dilihat fatwa Dewan Syariah Nasional tentang Sertifikat IMA, sebenarnya diterbitkan Sertifikat IMA dalam kegiatan investasi di pasar uang antarbank tidak lepas bahwa Islam memperbolehkan atau membenarkan umatnya melakukan transaksi muamalah seperti jual beli, sewa menyewa, hutang piutang dan lain-lain. Selain itu, tentunya juga terkait erat dengan adanya fatwa Dewan Syariah yang sebelumnya tentang bolehnya Mudharabah yakni fatwa No 07/DSN-MUI/IV/2000 dan fatwa No.36/DSN-MUI/X/2002 tentang bolehnya pasar uang antarbank.

Pemindah tanganan Sertifikat IMA hanya dapat dilakukan oleh penanam dana pertama, sedangkan bank penanam dana kedua tidak didapat memindah tangankan kepada bank lain sampai dengan berakhirnya jangka waktu. Hal ini Agar bank penerbit Sertifikat IMA dapat melakukan pembayaran kepada bank yang berhak, maka pemegang Sertifikat IMA yang terakhir berkewajiban memberitahukan kepemilikan sertifikat tersebut kepada bank penerbit. Hal ini sesuai dengan kaidah ushul fikih (Djazuli, 2010:147):

$$
\text { تصرّف الإمام على الرّ عية منوط بالمصلحة. }
$$
berlaku."

Artinya: "tindakan pemegang otoritas harus mengikuti mashlahah yang 
Oleh karena itu Bank Indonesia sebagai otoritas moneter memiliki kewenangan untuk membatasi jual beli sertifikat IMA hanya satu kali pasar sekunder. Pembatasan tersebut dilakukan untuk mencegah kesan terjadinya jual beli dana yang menjurus kepada kegiatan spekulatif. Sebelum pemberlakuan fatwa DSN tentang IMA ini, Bank Indonesia selaku lembaga yang berwenang memberikan kebijakan terkait lembaga keuangan juga telah telah terlebih dahulu mengeluarkan peraturan Bank Indonesia nomor 2/8/obi/2000 tentang Pasar Uang antar Bank Berdasarkan Prinsip Syariah. Dan baik peraturan bank Indonesia dan fatwa DSN terkait hal ini juga saling menguatkan.

\section{Fatwa DSN Tentang Mudharabah Musytarok Pertama: Ketentuan Umum}

Mudharabah Musytarakah adalah bentuk akad Mudharabah di mana pengelola (mudharib) menyertakan modalnya dalam kerjasama investasi tersebut.

\section{Kedua: Ketentuan Hukum}

Mudharabah Musytarak boleh dilakukan oleh LKS, karena merupakan bagaikan dari hukum mudharabah.

\section{Ketiga : Ketentuan Akad}

a) Akad yang digunakan adalah akad Mudharabah Musytarakah, yaitu perpaduan dari akad Mudharabah dan akad Musyarakah.

b) LKS sebagai mudharib menyertakan modal atau dananya dalam investasi bersama nasabah.

c) LKS sebagai pihak yang menyertakan dananya (musytarik) memperoleh bagian keuntungan berdasarkan porsi modal yang disertakan.

d) Bagian keuntungan sesudah diambil oleh LKS sebagai musytarik dibagi antara LKS sebagai mudharib dengan nasabah dana sesuai dengan nisbah yang disepakati.

e) Apabila terjadi kerugian maka LKS sebagai musytarik menanggung kerugian sesuai dengan porsi modal yang disertakan.

\section{Keempat: Ketentuan Penutup}

1) Jika salah satu pihak tidak menunaikan kewajibannya atau jika terjadi perselisihan di antara para pihak, maka penyelesaiannya dilakukan melalui Badan.

2) Fatwa ini berlaku sejak tanggal ditetapkan, dengan ketentuan jika di kemudian hari ternyata terdapat kekeliruan, akan diubah dan disempurnakan sebagaimana mestinya.

\section{ANALISIS}

Fatwa DSN-MUI No. 50/DSN-MUI/III/2006 menjelaskan kemungkinan aplikasi mudhabarah musytarakah dalam LKS. Ketentuan 
aplikasi akadnya adalah dimungkinkannya mudharib untuk menyertakan modal sendiri dalam akad mudharabah dan pembagian kentungan bisnis dilakukan untuk basis musyarakah selanjutnya basis mudharabah. Dalam hal terjadi kerugian, LKS menanggung kerugian sebesar porsi modal sebagai mitra syirkah.

Mudharabah musytarakah adalah ekstensi dari akad bagi hasil utama (mudharabah dan musyarakah) yang berorientasi untuk investasi sektor rill. Penjelasan mudhrabah musyarakat dapat dijelaskan melalui beberapa tahapan yaitu: Pertama, kedua belah pihak antara bank Syariah dan nasabah melakukan kerja sama dalam proyek atau bisnis. Kedua, di mana kedua belah pihak melakukan kontribusi baik dalam modal maupun sebagai pengelola dalam menjalankan usahanya, bank Syariah selaku shahibul maal memberikan dananya dan nasabah selaku mudharib dan juga shohibul maal, karena selain sebagai pengelola nasabah juga melakukan kontribusi dana, walaupun besarannya tidak sama dengan bank Syariah. Ketiga, kemudian kontribusi dari kedua belah pihak digunakan untuk menjalankan suatu proyek atau usaha bisnis. Keempat, bisnis berjalan dan apabila mengalami keuntungan, maka hasil keuntungan dibagi kedua belah pihak baik bank Syariah maupun nasabah sesuai dengan porsi modal yang diberikan. Kelima, apabila kerjasama tersebut sudah selesai dilaksanakan sesuai dengan jangka waktu yang disepakati, maka nasabah mengembalikan modal pokok bank Syariah (Wibowo, 2010).

Penggunaan akad selain bagi hasil dalam ekonomi Islam memang bukan sebuah aib. Tetapi dominasi akad tersebut akan memunculkan resiko reputasi (reputation risk) terhadap implementasi ekonomi Islam. Di mana pada akhirnya berkembang stigma bahwa ekonomi Islam tidak berbeda dengan konvensional. Eksplorasi terhadap akad mudharabah musytarakah dan kemungkinan implementasinya menggantikan masalahmasalah yang muncul dari implementasi mudharabah atau musyarakah murni adalah suatu langkah untuk memperkecil dominasi akad berbasis jual beli atau berpendapatan tetap. Impelementasi tersebut di antara dengan membentuk perusahaan join ventura yang membantu aplikasi akad bagi hasil yang efesien.

\section{KESIMPULAN}

Berdasarkan pembahasan terkait analisa terhadap beberapa fatwa terkait mudharbah yang ada, dapat disimpulkan bahwa secara keseluruhan fatwa yang ada sudah sesuai dengan ketentuan-ketentuan yang ada dalam khazanah keilmuan ekonomi Islam. Namun dalam melakukan konstruksi hukum sebagai legal sanding masih sangat global, khususnya dalam penggunaan kaidah usul fikih. Bahkan dari beberapa fatwa yang ada, ada kecenderungan yang sama dalam melakukan 
konstruksi hukum terhadap fatwa yang berbeda isi. Dalam tataran implementasi, sampai saat ini LKS belum sepenuhnya menerapkan fatwa ini, seperti setengah hati dalam menjalankan dan ada kecenderungan hanya dalam tataran formalitas formal seperti dalam jaminan.

\section{DAFTAR PUSTAKA}

Abdul Aziz Dahlan, Ensiklopedi Hukum Islam, jilid 4, Jakarta: Ichtiar Baru van Hoove, 1996.

Adhiwarman Karim, Bank Islam Analisis Fiqih dan Keuangan, Jakarta: PT Raja Grafindo Persada, 2004.

Antonio, Syafi'i, Bank Syariah Dari Teori ke Praktek, Jakarta: Gema Insani, 2001.

Djazuli, A, Kaidah-Kaidah Fikih: Kaidah-kaidah Hukum Islam dalam Menyelesaikan Masalah-masalah yang Praktis, ed. pertama, cet. ke-3, Jakarta: Kencana, 2010.

Hasan, M. Ali, Berbagai Macam Transaksi dalam Islam, Jakarta: Raja Grafindo Persada, 2003.

Hendro Wibowo, Mudharabah Musytarakah: Upaya Memperkecil Dominasi Fixed-Income Financing, Paper ini ditulis bersama Hendro Wibowo dan disampaikan pada Kolokium Nasional Sistem Keuangan Islam III School of Business Management - Institut Teknologi Bandung (SBM ITB), August, 2010. https://sepkymardian.wordpress.com /2013/02/25/mudharabahmusytarakah-upaya-memperkecil-dominasi-fixed-income financing/, di akses pada 28 Mei 2020.

Hisranuddin, Hukum Perbankan Syariah Di Indonesia: Pembiayaan Bisnis Dengan Prinsip Kemitraan, Yogyakarta: Genta Press, 2008.

http://irham-anas.blogspot.co.id/2011/04/analisis-fatwa-dsn-mui-tentangdeposito.html, di akses pada 28 Mei 2020.

Kompilasi Hukum Ekonomi Syariah

Mardani, Figh ekonomi Syariah: Fiqh Muamalah, Jakarta: Kencana, 2013.

Moleong, Lexy J, Metodologi Penelitian Kualitatif, Bandung: PT Remaja Rosdakarya, 2012.

Sahrani, Sohari, dan Ru'fah Abdullah, Fikih Muamalah: Untuk Mahasiswa UIN/IAIN/ STAIN/PTAIS, dan Umum, Jakarta: Galia Indonesia, 2011.

Sayyid Sabiq, Fikih Sunnah, Terjemah Abdurrakhim dan masrukhin, Cet ke-1, Jakarta: Cakrawala Publishing, 2009.

Suhendi, Hendi, Fiqh Mualamah, Jakarta: PT Raja Grafindo Persada, 2008.

Sula, Syakir, dan Aris Mufti, Amanah Bagi Bangsa Konsep Sistem Ekonomi Syariah, Jakarta: MES dan MUI, BI, Dept. Keuangan RI.

Syirbini, Syeikh Samsuddin Muhammad bin Khotib, Mughni Muhjaj, Juz II, Beirut: Dar Al-Ma' rifah, 1997. 
Tamrin, Dahlan, Kaidah-kaidah Hukum Islam Kulliyah al-Khamsah, Malang: UIN-Maliki Press, 2010.

Zuhaili, Wahbah az-, Fikih Islam wa Adillatuhu, Terjemah Abdul Hayyie alKattani dkk., cet. ke-1, Jakarta:Gema Insani, 2011. 